Global injustice, pedagogy and democratic iterations: Some reflections on why teachers matter

Elaine Unterhalter, University College, London Institute of Education

Elaine.Unterhalter@ucl.ac.uk 


\section{Global injustice, pedagogy and democratic iterations: Some reflections on why teachers matter}

\section{Abstract}

The article argues for teachers matter because of their potential to engage in critical reflection on values associated with connecting the local, the national and the global and supporting those who are dislocated, who have no place, and with whom we share humanity and apsirations. It identifies some similarities between approaches to pedagogy and Benhabib's notion of democratic iteration. Both concepts suggest a navigation between the general, the particular and some of the complexities of their contradictions which can guide teachers' work. Frameworks from cosmopolitanism and the capability approach are explored for detail they provide on how this navigation can be considered in practice across differently politically constituted formations and diversely, unequally situated groups. Drawing on some reflections on work in an international classroom, the conclusion explores some of these navigations across inequalities.

Keywords: cosmopolitanism, capabilities, equity, pedagogy, democratic iteration How do teachers matter in a world marked by inequality, injustice and many failures of our attempts to institutionalise global human rights frameworks and address poverty? What aspects of these issues should teachers teach and how? If the space for reflection on these difficult problems is narrowing because of the parochial nationalisms associated with public testing regimes and particularly limited understandings of educational accountability, what should teachers do? How can they help build insights to guide wiser ways forward when the process of education reform in so many countries has come to focus on a very limited set of 
national, often primarily economic outcomes, and with teachers highly regulated to deliver on these? If pedagogy is made a mechanical set of skills to develop a narrow range of learning outcomes, what space is open, through formal education, to reflect on global injustices that touch all our lives?

This article approaches this problem by outlining a working definition of pedagogy that makes space for engaging with global injustice and inequalities. It draws on the ideas about democratic iteration developed by Seyla Benhabib(2006; 2011) to explore complex processes of public argument in relation to understanding rights, issues of sovereignty, exclusion and transnationalism. These political processes are linked with pedagogic relationships, and woven into a definition of pedagogy. Frameworks for addressing international inequalities drawing on cosmopolitanism, capabilities and features of equity are deployed to show how they can provide some of the organising ideas for the critical reflection on values associated with democratic iteration. Some practices of doing this in an international higher education classroom are presented as one riposte to the parochial nationalism of test driven cultures in education.

The argument is organised in four sections. It begins with some definition regarding pedagogy and the situated-ness of teachers and links their ethical engagements addressing inequalities with the notion of democratic iteration. In the second section some frameworks to engage the question of global injustice are presented with a review of the potential associated with cosmopolitanism (Brock, 2013a), the capability approach (Sen, 1999; Nussbaum, 2011) and some discussion of the concept of equity. This is by no means the full range of conceptualisations open to us in thinking about global inequalities, pedagogies and how teachers matter, but the combination has been selected as a 
preliminary framework which appears generative for articulating some of the values associated with pedagogies around global injustice. In the third part some vignettes of practice are presented. These are drawn from experience working in a university on education inequalities in a globally connected world, reaching across locales, and struggling to develop understanding. They consider how the frameworks and pedagogic practices connect and some of the navigations entailed. The conclusion revisits the nature of the problem of what teachers can do caught between a highly regulated education system, and the staggering inequalities and injustices of the contemporary world. It attempts to mark out a terrain for practice, which draws on democratic iteration and suggests as a starting point gaining insight through critical reflection on global injustices drawing on frameworks, such as cosmopolitanism and the capability approach, which allow space for the discussion of values, diversity, and teachers' agency .

Pedagogic relations and democratic iteration, The definition of pedagogy in particular national contexts draws on histories of educational thought, experiences with the establishment of education systems and accounts of teachers' work. However, a single definition of pedagogy is controversial. Recently the position of some countries in global legal tables of education outcomes have led to the branding and export of particular pedagogic styles, and the critique of others ( Auld and Morris, 2014; Morris, 2015). Alexander (2008, 45-6) notes how much the discussion of pedagogy by policy makers in England from the 1980s, tilted the axis away from teaching to learning. Young $(2013,2014)$ has argued for the centrality of understanding the social relations of knowledge in analysing learning in a globalizing world, linking pedagogy with knowledge and curriculum. Moore (2012), charts the focus of much teacher education in the 
UK on specific skills, discourses of charisma, and the invocation of reflective practice as a catchall to deal with a wide range of difficulties and experiences. Garrison (1997) highlights a different side of the coin of pedagogy concerned with love and wisdom. In meditating on the success of the Finnish education system in PISA tests over the last ten years Sahlberg (2011) reflects on the high values given to Finnish teachers' own extensive education and agency. These different approaches highlight how difficult it is to capture a single definition of pedagogy. Alexander suggests one which will underpin the analysis in this article, because it seeks to situates any definition of pedagogy both nationally and internationally, and combines aspects of practice, with consideration of knowledge, research and a range of values, all of which seem highly pertinent to considering what informs teachers' engagements with global injustice and inequality. Alexander defines pedagogy as

The act of teaching, together with its attendant discourse of educational theories, values, evidence and justifications. It is what one needs to know, and the skills one needs to command, in order to make and justify the many different kinds of decision of which teaching is constituted . (Alexander, 2008, 47)

This definition entails appreciating practice and reflections on day-to-day experience. It underscores how these are informed by particularly situated views of education policy, history, research, and understandings of knowledge. It acknowledges practice is animated by a range of values, which may be local, national or global in particular mixtures. Running through this definition is a sense of pedagogy mediating that feature of the work of teachers that stands between the general and the particular, the historical contextual and everyday agency. It is this dynamic that appears generative in thinking about how teachers matter in relation to developing understandings of global injustices and inequalities. 
This reverberation between the general and the particular in the definition of pedagogy echoes a central notion in Benhabib's work concerned with democratic iteration. Benhabib develops the concept of democratic iteration to convey 'how the unity and diversity of human rights is enacted and re-enacted in strong and weak public spheres, not only in legislatures and courts, but often more effectively by social movements, civil society actors, and transnational organisations working across borders. (Benhabib, 2011, 15). She thus uses the concept to navigate between concerns with the general and the particular. A definition of pedagogy, such as that used by Alexander, is similarly situated in the public sphere of the school, but also entails a range of enactments across borders between learners, teachers, families, civil society, knowledge communities and various kinds of transnational network. Attempts to enact some integrating but self critically constructed 'unity', acknowledging this diversity, makes up some of the texture of what teachers do, and one of the reasons they matter.

Democratic legitimacy, Benhabib argues, drawing on the work of Habermas and the Frankfurt School, rests on the existence of institutions and the processes available for discursive reflection on those institutions (Benhabib, 2011, 74). Thus the legitimacy of ideas about rights, equalities or social justice would derive both from national or cross national institutions, which establish these, and from practices of critical review. Pedagogic relationships rest on the existence of education systems, and, either formally or informally, in everyday practice, they may provide opportunities for reflection on these processes. However, the extent to which critical reflection is encouraged or supported varies considerably across contexts. Whether or not there are opportunities for reflection and 
discussion of local, national or global injustices is also highly dependent of the contexts in which different teachers work.

Behnabib sees democratic iterations as 'processes of interplay between democratic will and opinion formation, on the one hand, and constitutional principles on the other hand' (Benhabib, 2011,75). Thus pedagogic relationships, for example as outlined by Young (2014) mediating between different forms of knowledge, reflecting both on institutional conditions and the situated-ness of learners and teachers, are a part of democratic iterations. Pedagogic relationships, in acknowledging forms of knowledge that derive both from disciplines, institutions, individual situation, and the interplay between them, resonate with some of the key moves associated with the process of democratic iteration. Benhabib argues that the right to have rights can be established through a justifictory universalism, which has the potential to be 'non-essentialist, non-reductionist and deeply imbricated in the democratic project'(Benhabib, 2011, 12).Part of this process of establishing justificatory universalism acknowledges a generalized notion of the other and a concretely situated engagement with particular others (Behnabib, 1995; Benhabib, 2011). This two sided notion resonates with some of the discussion of what is entailed in thinking about pedagogies and how to mediate between forms of knowledge codified in disciplines at a general level and generated in situations or experiences at the level of the particular teacher or student . It also addresses some of the issues of the general and the particular in the enactment of care or reflections on rights and inequalities.

For Behanbib, democratic iterations entail a dialectic of rights and identities in the process of which the meanings of identities and rights claims are 'reappropriated, resignifed, and imbued with different meanings' (Behnabib, 2006, 67) On many pressing contemporary 
global issues there are no simple agreements. For example, there are markedly divided views on immigration, and no easy solutions are on the table regarding the millions of refugees and migrants, now exceeding the numbers at the end of World War 2 . Michael Ignatieff (2014) has characterised the current period as presenting a new world disorder, in which authoritarian regimes used the supercharged markets of capitalism to strengthen economic growth and curtail political opposition. When the economies built through these processes contract, as they have dramatically since the end of 2015 , there is a turbulent political fallout, in which established institutions are called into question (Piketty, 2016; Mason, 2016). Under these conditions the form of democratic iteration that seeks to understand both the relationship of things and the disputed frames through which people interpret them, requires particularly alert pedagogical practice. Teachers matter because they are well placed to learn both what is and be alert to a range of values to interpret this empirical world. In the next section I suggest a number of approaches drawn from cosmopolitanism and capabilities that could be useful in this process of engaging with global injustice and steering between different networks of obligation and different kinds of understanding of inequality.

Cosmopolitanism and capabilities: Diverse obligations, equalities and forms of equity While there are a number of discussion of how teachers approach global injustice, for example drawing on ideas about global citizenship or development education ( Andreotti, 2015; Marshall, 2009), I have focussed this discussion on some of the texture provided by the concpets of cosmopolitanism and the capability approach for thinking about these issues, as both have engaged the question of diversity, the general and the particular in different ways. Thus theorisations of cosmopolitanism have engaged with the question of 
scale in relation to understanding what duties we owe to people who are not citizens of the same country. Writers working with the capability approach have considered the question of how to engage the question of diversity, and many changing contexts, which has particular relevance for the wide range of situations in which teachers work daily. Their analysis focuses on the relationships between opportunities (capabilities) and what comes to realised (functionings), echoing the arc of connection made by the notion of pedagogy. I now want to unpack the ideas of cosmopolitanism and the capability approach a bit further in relation to some of the dynamics associated with pedagogies confronting global injustice and inequalities.

Cosmopolitanism is a term much contested. On the one hand it is used to describe a globalized elite, who have fashioned a world of free trade, information flows, widening inequalities, the consumption of luxuries, and positional goods, and used state and international institutions to further a 'duty free' culture that pays scant attention to the particularities of conditions on the ground (Harvey, 2013). On the other hand the term is also used in political philosophy to try to deliberate on the question of whether we owe anything above a bare minimum of ensuring rights to survival to people who are not citizens of the same country. A rich literature has developed on how to think about cosmopolitanism as a response to global injustices and forms of inequality (eg. Brock,2013a; Rovisco and Nowicka, 2013) and to some extent this has been taken up in work on education, both positively eg. (Hansen, 2011; Hayden, 2012) and doubtfully (Popkewitz, 2012; Harvey, 2013). David Hansen (2011) has associated cosmopolitanism with teaching in schools and some of the processes of moving together and apart that meld the global and the local. Starkey (2012) outlines some principles of a shared humanity associated with 
rights and cosmopolitan utoipas Some feminist versions look beyond the sovereignty of states and develop notions that link recognition of vulnerability, and an ethics of care and mourning (Butler, 2010) or with responsibilities across global lines of association (Young, 2011) .Others identify forms of subaltern cosmopolitanism that link together experiences of dispossession (Zeng, 2014) and identify cosmopolitanism as a term whose meaning is struggled over, with concerns of situatedness and contradiction a major area of contestation (Schiller and Irving, 2015). Benhabib (2011 )links cosmopolitanism with democratic iterations and critical reflections on national and transnational frameworks of rights and wider formal notions of obligation. It can be seen that cosmopolitanism, shares with Alexander's definition of pedagogy a dynamic of stretching between the universal and the particular, with some writers problemastising this and some denying its significance.

All the work on cosmopolitanism, as an investigation of obligations enacted juridically or pedagogically, considers the question of how we practice connection across a general idea of rights, responsibilities, vulnerability. This work acknowledges there is a distinction between what we construct as abstract and particular, and some of the astute discussion (eg Vallentini, 2013; Moellendorf, 2013) draws out how important it is to make distinctions. Thus part of teachers' pedagogical work entails thinking about the space occupied by the local, the national, the global, their intermixture, and the terrain between drawing on some of the ideas the cosmopolitan debate has generated about moral equality, forms of national and global belonging, the rights held by the poor, and responsibilities beyond borders (Brock, 2013b; Berliner and Irving, 2015). The debate around cosmopolitanism between supporters and critics, gives content to a pedagogy that can help to place ourselves and our relationships on a map of critically examined values. One feature of this might 
entail understanding how these boundaries are experienced by those who are dispossessed or deligitimated. Another might be distilling how experiences of pain and loss are articulated and understood in a world of marked inequalities . A third might entail appreciating the power play and contestation operating in international relations at the different levels. Different curricular spaces or moments in a day of teachers' work open different terrains. How is this diversity of spaces to be navigated? The capability approach, as a method of analysis gives some pointers.

The capability approach gives a central focus to human diversity, and the link between opportunities or capabilities, and functionings, that is valued 'doings and beings' (Sen, 1999; Nussbaum, 2011). Capabilities can be more flexible than rights in thinking about inequalities in diverse local, national and global settings. Diversity takes many forms, highlighting both multiple contexts, but also a range of different kinds of inequality. Sen's famous question was initially posed in relation to inequality of what (Sen, 1980). Frances Stewart (2001) has outlined vertical and horizontal inequalities, which I have referred to as concerned with the inequality of whom (Unterhalter, 2015a). I have also identified a third facet of thinking about inequality, which I have termed an engagement with the inequality of how, which I see as a particular feature of work in education and of pedagogy (Unterhalter, 2015 a).

Sen's classic work (1993), posed the question regarding the value of equality. If we are to distribute benefits and burdens between people equally, as we all share the planet, what dimensions of people's lives should be compared in order to establish whether one person is worse off than another? Sen answered we should not simply equalise resources, or utility, but rather capabilities, opportunities and a connection between means and ends. This 
answer highlights a very significant role for teachers and pedagogic relationships. In defining inequality of what in terms of Sen's notion of capabilities we are looking, not simply at resources, or amounts, that is number of years of education or to what level someone can read, do mathematics or achieve in PISA tests. We are comparing what opportunities people do or do not have to fulfil what it is they have reason to value. Teachers matter partly because they may help ameliorate unequal national or global division of resources or guide reflections on what people want. They may offer opportunities to understand a world of injustice and inequality and engage critically with the institutions which form that.

A second feature of inequality and global injustice concerns inequality of whom. Frances Stewart (2009) has distinguished between what she calls vertical and horizontal inequalities. Vertical inequalities concern what is distributed, for example education or work opportunities or outcomes. She contrasts these with horizontal inequalities, which exist between groups constructed on the basis of race, ethnicity, gender, or class. Horizontal inequalities often attach to ideas such as religious beliefs, cultural or political or gender values. They are often deep seated, intersecting and work at levels that are both rational and emotional. The bodies, feelings and emotions of one group are lauded, and those of another reviled. A troubling aspect of horizontal inequalities is the depth of the hatred, racism, misogyny, xenophobia or violence, that can be passed down over generations. Indeed it may be that the formal structures of an education system do not admit these forms of inequality, but informal processes associated with neighbourhoods, friendships, marriage, and intra-generational belonging, maintain these inequalities and making redress of vertical inequalities much more complex. Vicious words exist in just about every language for women who do not conform sexually or intellectually. Women's bodies and 
forms of dress often demarcate the boundaries of belonging within nations and in transnational migrant communities (Yuval-Davis and Anthias, 1989; Anthias and Yuval Davis, 1993; Yuval Davis, 2011 Anthias, 2011). These hatreds also attach to men from subordinated groups, and are often phrased in terms of insults around sexuality .

To signal some of the ways this expands Sen's discussion of inequality the question Stewart is concerned with may be phrased as inequality amongst whom. This raises the questions of how to craft pedagogic relationships to breach silences, unravel some of the assumptions around identities and violence, and review intersecting inequalities. This suggests some indepth work pedagogic work by teachers that engages the complexity of the democratic iterations,

Teachers are crucial transmitters of ideas about horizontal inequalities. They are also key actors in helping to unpick the forms in which they are constructed and reproduced. Pedagogic relationships may use instruction, appropriately sequenced or scaffolded disciplinary knowledge, other forms of reflection on information and experience or some combination One of the problems around advancing insight into this area are the gaps in our knowledge, and the ways in which academic knowledge is often out of step with the lived experiences of inequality. This begs questions about professional distance, dispassionate evaluation, how we gather information, make connections and judgments. How teachers address the inequalities of whom, has been documented in particular areas concerned with race, gender, ethnicity or inability, but much work needs to be done on considering these intersections.

A third form of inequality, not covered by the geometric notions of vertical and horizontal inequality, talks to education as a site of process and practice and I have termed this aspect 
of diversity a consideration of the inequality of how (Unterhalter, 2015a). This form of procedural inequality sets in place particular kinds of hierarchies between, for example, teachers and learners which overlay the inequalities of distribution and recognition associated with horizontal and vertical inequalities. Education is a site of many procedural inequalities. For example it encodes differences of age, most evidently between adults and children, but also between children of different age group, and in higher education between older and younger academics. In all phases there are inequalities across hierarchies of employment and decision-making. There are inequalities in educational experience and resources, given the vast differences between institutions working in the same phase. There are inequalities between formal and informal knowledge areas, between the status of disciplines and research methodologies, forms of curricular knowledge, and in the regard given to empirical and theoretical accounts of particular problems, such as global injustice. There are inequalities between teachers regarding the severity of the regulatory regimes they are subject to, and between approaches to curricula that compel conformity and those that encourage deliberation. Curriculum selection is associated with inequality of how. Thus the identification of powerful knowledges, how this is organised, sequenced and evaluated contributes to this form of inequality. The democratic iterations I have linked with pedagogy require some naming of these inequalities of how, and pedagogies which engage them entail some thoughtful practices to navigate across these divisions, unequal locations and relationships, considering both the universal and the particular.

What are the processes through which these different facets of inequality can be navigated, and addressed pedagogically? Equity is a term which, together with cosmopolitanism can illuminate some of the ways teachers can engage in pedagogic relationships which address 
different kinds of global inequalities. To illustrate some possibilities I draw on some work I have done looking at the changing meanings of equity in English. (Unterhalter, 2009) The semantic history of the word equity and the social contexts in which it was deployed, indicate three different ways to think about its meanings. Each has particular implication for thinking about pedagogic relation. In its earliest form equity signalled an association between the powerful and the powerless, that accorded each equal moral worth, and signalled processes of participation in knowledge formation and joint learning. I have termed this equity from the below (Unterhalter, 2009, 417). In a later incarnation equity signalled the establishment of special courts that were neither the domain of the church nor the nobles, but regulated both. I have termed this equity from above (Unterhalter, 2009, 418-9 In the age of capitalism equity came to mean money or forms of capital and I have termed this equity from the middle (Unterhalter, 2009, 421).

Equity from above delineates how we might establish institutions nationally or transnationally, which secure people's rights to say health, education or livelihoods, facilitate fair forms of distribution, taking account of contexts of intersecting inequalities, but primarily addressing inequality of what and inequality of whom. This seems particularly appropriate to use in evaluating curricula used in teacher education and the extent to which they provide a scaffolding of ideas which address adaptive preference, and the form of inequality of what that makes it difficult for children in absolute poverty to articulate what it is they have reason to value (Unterhalter, 2013). Equity from above is also important in putting in place laws or institutional forms for schools or teacher education colleges which work to undo racism or gender discrimination, associated with horizontal inequality. But, we know through a host of studies, that making the institutional form will not in and of itself 
address the kinds of practice that perpetuate inequalities. This needs a different level of engagement. Equity from above seems to have affinity with a form of social justice cosmopolitanism concerned to develop the transnational institutions that can oversee or support the securing of rights, when national systems fail or are weak. This form of equity from above seems well suited to address some transnational monitoring of processes to secure equality of rights and some, but not all capabilities, possibly those linked with gender or forms of resource inequalities .

Equity from below is particularly attentive to forms of participation, mediating the relationships of the powerful and the powerless. I think this form of equity talks to engagements with inequality of how and inequality of whom $\mathrm{n}$ schools, classrooms, and lessons. It looks at processes by which learners and teachers are positioned in relation to particular forms of knowledge, pedagogic practice, how exclusions might be challenged, and inclusion addressed, how the multi-dimensionality of inequality, and particular registers around violence are understood and learners and teachers helped to confront and transform this (Parkes, 2015) .Equity from below evokes forms of subaltern cosmopolitanism, and it may be that the democratic iterations associated with pedagogic relationships, can help with listening to silences, disentangling particular themes, of pain and exclusion, although this requires time and space $t$ to secure.

I have linked equity from the middle with flows of money, technologies, expertise, and ideas, which enable equity from below to articulate with equity from above. Equity from the middle appears particularly salient in connecting the concern with the three different kinds of inequality I outlined. Teacher education, teacher deployment, teacher communication, conditions of work, teacher agency and professional ethics, are all 
instances of equity from the middle that need to engage with diversity and ways of linking the general and the particular. David Hansen (2011) has written about the ways in which people engage with reading the world, encouraging practices in classrooms that are at once global and local, expanding the scope of both. Democratic iterations and pedagogic relations depend on further theorising these processes in the middle. Pedagogic relationships of democratic iteration rest both on processes from below but also on building and supporting teachers to attend to transnational processes of securing rights, building frameworks of care, and circulating information about dispossession. In a recently completed study with newly qualified teachers in five Nigerian states, it is evident how little support young people entering teaching have had to understand the local, national or global contexts of the teaching skills they are given. (Unterhalter, 2016)

An important area for critical engagement with equity in the middle is the terrain of measurement, where there are opportunities both to use existing forms of measurement, like PISA to reveal some of the inequalities of what and inequalities of whom, as well as critical discussion of how we might better construct measures of equality in education that consider some of the features of inequality of how as it plays out across global, national and local sites through gender relations (Unterhalter, 2015b) disabilities or other injustices (Klees and Quargha,2014). This suggests the importance of investigating how vertical, horizontal and procedural or pedagogic forms of inequality interconnect, and what this entails for the work teachers currently do and could be supported to do better. We need to investigate how or whether teachers' negotiations between different kinds of inequalities bridge aspects of the public and private, the analytical and experiential, the content of 
knowledge areas and the formation of particular dispositions and what supportive indicators of this process might be. What resources do teachers have to look at the roots of local, national and global inequalities and their connection ? We have very few studies of this in practice, but I surmise that where this happens there are particularly in-depth pedagogic encounters associated with well supported teachers, explicitly engaged with considering inequalities.

In this section I have explored some of the potential associated with the ways scholars of cosmopolitanism have tried to sort out the question of how we understand our relationships of general and particular obligation. I have also discussed how some of the appreciation of context, and different forms of inequality in the discussion of the capability approach, generates interest in features of equity and democratic iteration, that give content to the notion of how teachers matter, and some aspect of pedagogy. Teachers matter because they reflect critically on the education, political and social systems in which they are located, and have some potential to engage with the inequalities of what, of whom and of how, addressing relationships that are top-down, bottom up, and through the middle. In the next section I reflect on some of my own practice in an international classroom, trying to draw out some of the pedagogic relationships that are in play, highlighting some of the ways pedagogic relations matter.

Some pedagogic relationships in a transnational classroom

I have worked for 25 years with a diverse student body at the Institute of Education, University of London (now University College London, Institute of Education) teaching on Masters. courses I have selected four learning moments to evoke some of the complexity of pedagogic relationships associated with global injustices and have tried to draw out how 
some features of cosmopolitanism, democratic iteration, and capabilities are at play, and why teachers matter.

The setting is a university which provides considerable support for students. Excellent library and information services, experienced teachers and administrators articulate peers, combine with London as a global city and a resource in itself. But these advantages are mediated. The university provides benefits because fees are high. Staff experience rests on combinations of teaching and research which impose boundaries of time and space on the pedagogic relationships that can develop. Students and staff bring to the classroom divergent experiences with, and perspectives on, the structures of inequality, intersecting race, ethnicity, gender, and class. Agreements are not pre-given. Differences in language, access to cultural and other forms of capital can separate students from each other and from their teachers. London as a global city is linked as much with the injustices associated with slavery and the expansion of capitalism, as it is with the growth of equalities and struggles for justice. Thus in practice as a teacher one has many tasks. Some entail bridging the differences between learners, between any particular learner, and oneself, and the interpretation of the curriculum different learners make. Other tasks entail a scaffolding of a critical reflection on where we are in time and space, with the knowledge we are reviewing. We are also engaged in ensuring some insight into the inequalities of opportunities in education round the world and how to confront them. The democratic iteration in the classroom is one that entails moving between the concrete particular, and the generalised frame.

The mission statement for the section of the Department in which I work, frames our engagement with 'the protection and advancement of rights and capabilities in education at 
all levels' (EID, 2013). We are concerned with preparing students 'to become competent, confident and critical professionals who can analyse education and related policy, research and practice issues at a high level of analytical rigour with appropriate regard to context.' The instances I present below are ones where engagements with global injustice were almost beyond words and academic frameworks. In these four vignettes the pedagogic relationships evoke searchings in a world that is simultaneously striving for forms of order and connection, as epitomised by research and teaching, yet is also disordered, unravelling, difficult to describe, increasing inequalities, injustices, and disorganising pedagogic projects. In teachers trying to reflect on this, they make a space in which it is clear that what they do matters.

Miwako Tokuda, was born on Okinawa, a Japanese island invaded by American troops at the end of World War 2. The trauma of that time was intense. As the Americans advanced, Okinawan families were instructed by the military hierarchy that they should kill themselves, rather than risk dishonour through capture. Many complied. Miwako's grandfather and some aunts survived. She wanted to interview them to explore memory, gender, and catastrophe. But the pain of doing so was too acute. Her dissertation Someone is listening (Tokuda, 2005) was an attempt to try to work out what this silence might mean for teaching and learning about extreme events, and the work was developed through many conversations between Miwako and I, members of her close family, and some of her classmates .

Kay Andrews, a specialist in teaching in schools about the Holocaust in Europe, wrote her Masters dissertation on some of the silences in Holocaust education about gender, linking this with ways in which memorials to the genocide in Rwanda have remembered and 
forgotten women (Andrews, 2013). She grappled with how to evaluate intersecting injustices, and bring this learning into thinking about how to memorialise genocides across different settings. She worked with an extensive body of written scholarship on this theme, her conversations with colleagues, and her dialogues in supervision with me.

A student revealed to me that he had been a child soldier in the Biafran war in the 1960s. Now a well established professional in the UK, he was keen to understand education and international development. I hoped his experiences would provide some unique perspectives on the literature on child soldiers. But the compressed time frame of a short module distorted our pedagogic relationship and seemed to get in the way of learning. The literature on child soldiers is written from the outside, while his experiences and memories were complex requiring many layers of exploration. I failed to help him make connections.

Lucky Omaar, studied for her MA after travels between Somalia, Kenya, USA and UK, experiencing the pains and upheavals of the Somali diaspora. While working on her dissertation (Omaar, 2015) with young Somali women, living in Kenya, terrible atrocities perpetrated by Al Shabab took place. Was there a place for reflections on these events in the dissertation, or was our pedagogic relationship to be structured by keeping to academic timetables and formal lines of reflection? Lucky and I discussed this extensively, and she also reflected with other students, academic and administrative staff, and her networks in Kenya.

I have selected these four examples because they highlight features of injustices and inequalities of our contemporary world, the legacies of colonialisms, wars, the difficulties and silences for those who survive. They point to the complexity of pedagogic relationship suggesting the difficulties of teaching and learning in a global classroom, trying to listen to 
silenced and oppressed voices, and some of the achievements of expanding understanding through in-depth work and the wide range of networks that support this teaching. They distil some of the concerns of the cosmopolitanism discussion with the moral equality of each and every human being. They also show students engaging with addressing the inequality of how, navigating across vast political, social and generational differences and deliberating both about what amounts of education to distribute, given very different experiences, and the content of that education. All four address how different educational moments - listening, memorialising, reflecting, or connecting - might offer opportunities to engage with the inequalities of whom. All, as processes of learning linked with research, attempt to use conceptual framings, data, and critical reflection to navigate some of the inequalities of how, listening across generations, different experiences of genocides or dispossession. The pedagogy entailed in my work with the students entailed a very alert attention to this inequality of how, much easier to realise through the in depth work of the dissertation, and not full accomplished in the work of the student whose thinking was confined to the 5000 word essay. The vignettes are presented to show how pedagogies matter, and require constant critical reflection on why some kinds of engagements with global injustice are more fully realised as moments of democratic iteration, and others appear to close off insight.

\section{Conclusion}

This article has reflected on different forms of inequality and some of the pedagogic relationships entailed in thinking about global inequalities and injustice. The discussion has considered how deploying ideas about different kinds of inequalities and different kinds of 
obligations, drawing on frameworks from cosmopolitanism and the capability approach can enhance processes of democratic iteration and help to deepen understandings of these processes for learners and teachers grappling with aspects of global injustice and conditions of plurality, connection and uncertainty. Reflecting on some of my own work, and those who have studied with me, the analysis highlights the considerable resources needed of time, space, social networks, theoretical and empirical engagement, and complex understandings of the relationships of the middle, that work across top-down and bottomup settings. For many teachers working in schools, universities and colleges of education under conditions of pressure and constrained resource, in depth pedagogic encounters of this sort may indeed be difficult to achieve or sustain . Nonetheless, public education and the pedagogic relationships within it remains an iterative space of possibility. More than three million people around the world voted in the on line poll regarding the world we want post 2015 . The largest vote across all age groups, men and women, and all regions was for a good education. If the world we want is an educated world, teachers matter crucially. The pedagogic relationships they can develop will help us articulate our visions of global justice, sustainability and equity and allow us to look critically at different kinds of inequality and forms of belonging. Thus central to some of the concerns with addressing global injustice are engagements with teeachers' agency, support for out capacities as teachers to understand and address different kinds of inequalities, and continuing to give reflective depth to how we draw on skills of negotiating the general and the particular to take forward concerns with equity. 


\section{References}

Alexander, R. 2008, Essays on pedagogy Abingdon: Routledge

Andrews, K., 2013, Unpublished MA dissertation, Institute of Education, University of London

Andreotti, V. O. (2015). 'Global citizenship education otherwise' in A. Abdi ed. Decolonizing global citizenship education Rotteerdam: Sense, 221-229

Anthias, F., \& Yuval-Davis, N. (1993). Racialized boundaries: Race, nation, gender, colour and class and the anti-racist struggle.London: Routledge.

Anthias, F. (2008). Thinking through the lens of translocational positionality: an intersectionality frame for understanding identity and belonging. Translocations: Migration and Social Change, 4(1), 5-20.

Auld, E., \& Morris, P. (2014). Comparative education, the 'New Paradigm'and policy borrowing: constructing knowledge for educational reform. Comparative Education, 50(2), 129-155.

Benhabib, S. 2011, Dignity in Adversity : Human rights in troubled times Cambridge: Polity

Benhabib, S. 2006 Another cosmopolitanism Oxford: Oxford Univeristy Press

Brock, G. (Ed.). (2013a). Cosmopolitanism Versus Non-cosmopolitanism: Critiques, Defenses, Reconceptualizations. Oxford: Oxford University Press.

Brock, G. (2013b) 'Rethinking the cosmopolitanism versus non-cosmopolitanism debate: An introduction' in Brock, G. (Ed.). . Cosmopolitanism Versus Non-cosmopolitanism: Critiques, Defenses, Reconceptualizations. Oxford: Oxford University Press, 1-34.

Butler, J., 2010, Frames of war London: Verso 
.Education and International Development (EID), 2013, 'Mission statement of the Education and International Devleopment section of the Department of Humanities and Social Science' Statement adopted by staff of the EID section, November

Garrison, J., 1997, Wisdom and desite in the art of teachingNew York: Teachers' College Press

Harvey, D. (2013). Cosmopolitanism and the Geographies of Freedom. New York: Columbia University Press.

Hayden, M. J. (2013). Arendt and cosmopolitanism: the human conditions of cosmopolitan teacher education. Ethics \& Global Politics, 5(4).

Hansen, D. (2011). The Teacher and the World: A Study of Cosmopolitanism as Education. Teacher Quality and School Development. Routledge, Taylor \& Francis Ignatieff, M.,. (2014). The New World Disorder. The New York Review of Books, September $25^{\text {th }}$

Klees, S. J., \& Qargha, O. (2014). Equity in education: The case of UNICEF and the need for participative debate. Prospects, 44(3), 321-333.

Marshall, H. (2009). Educating the European citizen in the global age: engaging with the post-national and identifying a research agenda. Journal of Curriculum Studies, 41(2), 247-267.

Mason, P. (2016). Postcapitalism: A Guide to Our Future. London: Macmillan.

Moellendorf, D. , 2013 , 'Human dignity, associative dutes, and egalitarian global justice’ in Brock, G. (Ed.). Cosmopolitanism Versus Non-cosmopolitanism: Critiques, Defenses, Reconceptualizations. Oxford: Oxford University Press, 222-238.

Moore, A. (2012). Teaching and learning: Pedagogy, curriculum and culture. Routledge. 
Morris, P. (2015). Comparative education, PISA, politics and educational reform: a cautionary note. Compare: A Journal of Comparative and International Education, 45(3), 470-474.

Nussbaum, M., 2011, Creating capabilities Cambridge Ma: Harvard Univeristy Press

Omaar, L., 2015, ' Investigating the dynamics of displacement among Somali female refugee students in Eastleigh, Nairobi' . Dissertation prepared for MA in Education, Gender and International Development, University College London, Institute of Education.

Parkes, J. (Ed.). (2015). Gender Violence in Poverty Contexts: The Educational Challenge. Abingdon: Routledge.

Piketty, T., 2016, Chronicles on our troubled time London: Viking

Popkewitz, T. S. (2012). Cosmopolitanism and the age of school reform: Science, education, and making society by making the child. Routledge.

Rovisco, M., \& Nowicka, M. (Eds.). (2013). The Ashgate research companion to cosmopolitanism. Ashgate

Sahlberg, P. (2011). Finnish lessons. New York: Teachers College Press.

Schiller, N. G., \& Irving, A. (Eds.). (2014). Whose Cosmopolitanism?: Critical Perspectives, Relationalities and Discontents. Berghahn Books.

Sen, A., 1999, Development as freedom Oxford: Oxford University Press

Sen, A., 19992 Inequality rexamined. Oxford: Clarendon Press

Starkey, H. (2012). Human rights, cosmopolitanism and utopias: Implications for citizenship education. Cambridge Journal of Education, 42(1), 21-35.

Stewart, F. (2000). Crisis prevention: Tackling horizontal inequalities. Oxford Development Studies, 28(3), 245-262. 
Stewart, F. (2009). Horizontal inequality: two types of trap. Journal of Human Development and Capabilities, 10(3), 315-340.

Tokuda, M., 2005, 'Somebody is listening : making and remaking of memories of Okinawan women' Unpublished MA dissertation, Institute of Education, Univeristy of London

Unterhalter, E. (2009) 'What is equity in education? Reflections from the capability approach' Studies in the Philosophy of Education,28, 5, 415-424.

Unterhalter, E. (2012). Inequality, capabilities and poverty in four African countries: girls' voice, schooling, and strategies for institutional change. Cambridge Journal of Education, 42(3), 307-325.

Unterhalter, E., 2015a, 'Analysing inequalities in education ' in McCowan, T.and Unterhalter, E., Education and International Development: An introduction London: Bloomsbury. 127-148 Unterhalter. E 2015b Measuring gender inequality and equality in educaiton' Concept paper prepared for UNGEI workshop, London, September 2015

Unterhalter, E., 2016, 'Teacher education, teacher practice, gender and girls' schooling outcomes' Executive Summary of Research Report. Abuja: British Council

Young, I.M, 2011, Responsibility for Justice Oxford: Oxford University Press

Young, M. (2012). Education, Globalization and The 'Voice of Knowledge'. In Livingstone, D. and D. Guile, eds. The Knowledge Economy and Lifelong Learning Rotterdam: SensePublishers pp. 335347.

Young, M. (2013). Overcoming the crisis in curriculum theory: A knowledge-based approach. Journal of curriculum studies, 45(2), 101-118.

.Yuval-Davis, N., \& Anthias, F. (Eds.). (1989). Woman, nation, state. London: Macmillan. Yuval-Davis, N. (2011). The politics of belonging: Intersectional contestations. London: Sage. 
Valentini, L., 2013, Cosmolitan justice and rightful enforceablility' in Brock, G. (Ed.).

. Cosmopolitanism Versus Non-cosmopolitanism: Critiques, Defenses, Reconceptualizations.

Oxford: Oxford University Press, 92-110.

Zeng, M. (2014). Subaltern cosmopolitanism: concept and approaches. The Sociological Review, 62(1), 137-148. 